University at Buffalo School of Law

Digital Commons @ University at Buffalo School of Law

Journal Articles

Faculty Scholarship

6-20-2021

\title{
Our Imperial Federal Courts
}

Matthew J. Steilen

University at Buffalo School of Law

Follow this and additional works at: https://digitalcommons.law.buffalo.edu/journal_articles

Part of the Comparative and Foreign Law Commons, and the Legal History Commons

\section{Recommended Citation}

Matthew J. Steilen, Our Imperial Federal Courts, 74 Vand. L. Rev. En Banc 125 (2021).

Available at: https://digitalcommons.law.buffalo.edu/journal_articles/1013

\section{C) ${ }_{\text {COPYRIGHT }}^{\text {N }}$}

This Article is brought to you for free and open access by the Faculty Scholarship at Digital Commons @ University at Buffalo School of Law. It has been accepted for inclusion in Journal Articles by an authorized administrator of Digital Commons @ University at Buffalo School of Law. For more information, please contact lawscholar@buffalo.edu. 


\title{
Response
}

\section{Our Imperial Federal Courts}

\author{
Matthew Steilen*
}

I. AnXiety About the NATURE of LEGAL Authority .............. 129

II. THE IMPERIAL SHADOW OF ENGLish ANXIETy ABOUT

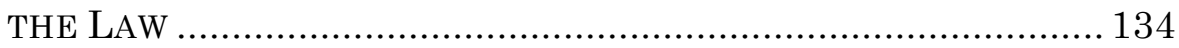

III. The Institutional Dimension of InTELLECTUAL ANXIETY

AND ITS CONNECTION TO LOCAL POLITICS ............................ 138

The study of legal history took an imperial turn some twenty years ago. In a book review published in 2007, John Fabian Witt, a leading historian of military law, remarked that "[o]ld-fashioned empire" was "suddenly everywhere." ${ }^{2}$ Empire had been the subject of a series of lengthy institutional studies, written around mid-century, that described the formal legal structures of transnational enterprise and government during the seventeenth and eighteenth centuries. ${ }^{2}$ The new studies that had caught Witt's eye were nominally concerned with the same subject. But there are also significant differences. The new studies tended to rely on different sources: rather than acts of Parliament, opinions of the courts at Westminster, and the charters, commissions,

\footnotetext{
* Professor, University at Buffalo School of Law, State University of New York. This essay is a response to Christian R. Burset, Advisory Opinions and the Problem of Legal Authority, 74 VAND. L. REV. 621 (2021). I want to thank Professor Burset and editor Shivam Bhakta for the invitation. I also want to thank Fred Konefsky for his helpful suggestions.

1. John Fabian Witt, Anglo-American Empire and the Crisis of the Legal Frame (Will the Real British Empire Please Stand Up), 120 HARV. L. REv. 754, 754 (2007) (book review).

2. For example, see Joseph Henry Smith, Appeals to the Privy Council From the American Plantations (1950); Julius Goebel, JR. \& Thomas RAymond NAughton, LaW Enforcement in Colonial NeW YorK: A Study in Criminal Procedure (1664-1776) (1944); LEONARD WoOds LABAREe, ROYAL GOVERNMENT In AMERICA: A STUDY OF THE BRITISH COLONIAL SYSTEM BEFORE 1783 (1930). Here you might also fit the old casebooks in "Development of Legal Institutions," including JosePH H. SMiTh, CASES AND MATERIALS ON THE DEVELOPMENT OF LeGAL Institutions (1965); John Philip Dawson, The Development of Law and Legal Institutions (1968) (unpublished manuscript). Professor Dawson's unpublished manuscript became the basis for the contemporary casebook by John Langbein, Renee Lerner, and Bruce Smith. JoHN H. LANGBEIN, RENÉE LeTtow LeRner \& BRuce P. SMith, History of the Common LAW: The Development of ANGLO-AMERICAN LEGAL INSTITUTIONS xxvi (2009).
} 
and orders of the Privy Council, the new studies focused on writings produced by the individuals navigating frontier encounters, like orders, letters, journals, and newspaper items. The analytic framework was different: the old construct of a "first British empire" gave way to multiple imperial projects, intersecting with diverse populations of settlers and enslaved or indigenous peoples, each with their own purposes. The voice and narration were different: in contrast to the disembodied character of the old-fashioned studies, the new accounts were granular, dynamic, and more revealing of human experience and activity in administration. Looking back now, twenty years out, it seems right to conclude that this change in approach was fruitful, producing a deeper understanding of colonialism, the imperial crisis and American Revolution, and the projects of constitution-making and western expansion that followed. ${ }^{3}$

But though legal history took an imperial turn, many other areas of legal scholarship did not. For some subjects this seems appropriate; for others it is surprising. For instance, although the literature of constitutional law has long been historical, ${ }^{4}$ much of it remains domestic on principle and stubbornly institutional. A glance at the leading law reviews suggests that most legal scholarship is doctrinal-a form of history-but without much attention to the significance of these boundaries to the study.

The effect has been to open a gap between historical scholarship and cognate studies in the law. For example, the nature of the federal judicial function is a topic with significant historical content, touching on some of the same subject matter as our new imperial legal histories; yet the perspective remains essentially national, framing the federal courts as a response to concerns with national revenue, debt, and matters of foreign policy like the enforcement of treaties, jurisdiction over aliens, and captures at sea. As Professor Burset explains, some aspects of the topic, like the ban on advisory opinions, are understood in exclusively domestic terms (with a compulsory nod to relevant

3. Major contributions to this line include LAUREN BENTON, LAW AND COLONIAL CULTURES: LEGAl REgimes in World History, 1400-1900 (2002); DANiEl J. Hulsebosch, Constituting EMPIRE: NEW YORK AND THE TRANSFORMATION OF CONSTITUTIONALISM IN THE ATLANTIC WORLD, 1664-1830 (2005); Mary SARAH Bilder, The Transatlantic Constitution: Colonial Legal Culture and the Empire (2004); Eliga H. Gould, Among the Powers of the Earth: The

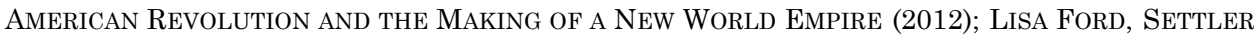
SOVEREIGNTY: JURISDICTION AND INDIGENOUS PEOPLE IN AMERICA AND AUsTRALIA, 1788-1836 (2010); JACK P. Greene, The Constitutional ORigins of the AMERICAN Revolution (2011); Mary Sarah Bilder, The Corporate Origins of Judicial Review, 116 YALE L.J. 502 (2006).

4. G. Edward White, The Arrival of History in Constitutional Scholarship, 88 VA. L. REV. 485, 487 (2002). 
English precedents). ${ }^{5}$ This may be because the leading casebook in the field, Hart and Wechsler's The Federal Courts \& The Federal System, first published in 1953, was framed in response to a concern with the effect of modern federal jurisdiction on domestic divisions of power, principally between federal and state courts, and between Congress and the federal judiciary - a framing that subsequent editions of the book have largely retained. ${ }^{6}$ While there have been many contributions to the scholarly study of federal judicial power since Hart and Wechsler was first published, the giants of the field still hold a kind of magnetic power over its line of development.

To pull the study of advisory opinions off this course would require a contribution of considerable mass. Although it is now rare, a new source might do the trick, and this is what Professor Burset promises us here. He has made a study of the archival and published papers of judges in late-eighteenth century British-governed Bengal. ${ }^{7}$ What relevance could they have to the power of federal judges? As Professor Burset interprets them, those papers reveal British Bengali judges wrestling with the same concerns that led to the abandonment of advisory opinions in England and America. If judges in all three common-law jurisdictions decided to abandon advisory opinions around the same time, then their abandonment was "a global phenomenon that requires a transnational explanation." transnational explanation that Professor Burset offers is an intellectual one. The reason that judges across the common-law world abandoned advisory opinions was because of a breakdown in the "jurisprudential orthodoxy" that had treated judicial opinions as declarations of existing law. ${ }^{9}$ This breakdown led to an examination of what made statements of the law authoritative. Whether judicial advice should enjoy the same authority and status as opinions in litigated cases was unclear and disputed. In this intellectual context, Professor Burset argues, judges were unwilling to give advisory opinions for fear of how they might be used.

The article is significant for the archival work alone. It is useful, as well, for the impressive synthesis of the existing secondary literature, collected in the footnotes, which makes a convenient reading

5. See Burset, supra note *, at 623 .

6. Richard H. Fallon, Jr., Reflections on the Hart and Wechsler Paradigm, 47 VAND. L. REV. 953, 957, 962 (1994); see also Henry P. Monaghan, Hart and Wechsler's The Federal Courts and the Federal System, 87 HARV. L. REV. 889, 889 (1974) (book review).

7. See Burset, supra note *, at $643-50$.

8. Id., at 623 .

9. Id., at $623,659-60$. 
list for us mere mortals. The argument of the article is ambitious. As the Table of Contents suggests, its structure is complex: the author asks us to visit three different jurisdictions (two British and one American, each thousands of miles apart), in three different decades, in three different political and social contexts, with three different institutional frameworks. The author moves the reader discontinuously through time, interpreting each context both for its meaning to the historical actors embedded within it, and for its significance to contemporary constitutional law.

I want to use this Response to explore some of the complexities of this argument. I'd like to ask: What does it mean to give a "transnational" explanation? Is one actually necessary here, as the author avers? What place does the "local" have in such an explanation? Does a transnational explanation of the formal abandonment of advisory opinions actually rule out local factors and contributing causes-or does it, in fact, require them? What does it mean to give a transnational intellectual explanation-to explain the decline of advisory opinions by reference to an anxiety about their authoritative status? Intellectual causation is somewhat uncommon in contemporary legal history, which prefers to emphasize the "contingency" of legal ideas and institutions by attributing their adoption to material selfinterest or to the complex calculations that track the distribution of power in modern political societies. And what is the connection, exactly, between Justice Elijah Impey of the Supreme Court of Judicature in Bengal and Justice John Jay of the United States Supreme Court? Does their saying the same words, or expressing the same anxieties, mean they were moved by the same "idea," even if the men never actually communicated? ${ }^{10}$ What about the fact that they acted in different political, social, cultural, and institutional contexts?

These are not just questions for Professor Burset. They are questions for fellow-travelers on our twenty-year imperial journey. The new studies of empire often focus on individuals at the periphery. Are these studies of empire, or of those individuals? If we think of the empire as a formal structure of institutions and laws, precisely what does a study of its settlers and magistrates tell us about that structure? Do the formal structures of institutions and laws contribute anything to how those individuals experience the world around them and act on

10. See Quentin Skinner, Meaning and Understanding in the History of Ideas, in MEANING \& CONTEXT: QUENTIN SKINNER AND HIS CRITICS 29, 54-56 (James Tully ed., 1988). 
it? Does form contribute to experience? (This is a perspective I have tried to explore in my own work on colonial Virginia. ${ }^{11}$ )

In what follows, I won't try to answer these abstract questions themselves. Rather, I will sketch some of what I take to be the relevant history for understanding the abandonment of advisory opinions, but which is not part of Professor Burset's account. By adducing this material, my aim is to raise the larger questions by implication, and to get a sense, thereby, of the boundaries of Professor Burset's argument, and of the terms on which we might refine and incorporate it into our understanding of the nature of the federal judicial power.

\section{ANXIETY ABOUT THE NATURE OF LEGAL AUTHORITY}

It is now commonplace to observe that in the eighteenth century, judges were thought to have a purely declaratory function. They declared what the law was (jus dicere), rather than giving it (jus dare), or making it, as we say today when we speak of "judge-made law." Blackstone included this declaratory theory in his Commentaries, observing that the judge "is only to declare and pronounce, not to make or new-model, the law." 12 Why it should have been thought important to insist on this point is generally less discussed. This was not a theory of absolute stasis in the law, though it is sometimes described that way. Blackstone did not insist on the fiction that the common law had remained unchanged "since time immemorial," as had Edward Coke in the seventeenth century; indeed, Blackstone argued, adaptation constituted the chief advantage of the common law over statutory law. ${ }^{13}$ Many commentators regarded the mass of statutory law then being enacted by Parliament as confused, contradictory, oppressive, and inconsistent with English liberty. In contrast, the common law was the repository of English liberty, even though it had changed over time to meet new social problems. The point of the declaratory theory was to clarify the role of judges in the maintenance of English liberty. Judges

11. Matthew Steilen, The Legislature at War: Bandits, Runaways and the Emergence of a Virginia Doctrine of Separation of Powers, 37 LAW \& HIST. REV. 493 (2019).

12. WILLIAM BLACKSTONE, COMMENTARIES ON THE LAWS OF ENGLAND: BOOK III: OF PRIVATE Wrongs 216 (Thomas P. Gallanis \& Wilfrid Prest eds., 2016) (1768) (emphasis omitted).

13. David Lieberman, The Province of Legislation Determined: Legal Theory in EIGHTEENTH-CENTURY BRITAIN 72-73 (1989). Probably the best known expression of this view in the Commentaries is Blackstone's image of the common law as a "Gothic castle, erected in the days of chivalry, but fitted up for a modern inhabitant." BLACKSTONE, supra note 12, at 178. For Coke's view that the common law had remained unchanged since time immemorial, see J.G.A. PococK, THE ANCIENT CONSTITUTION AND THE FEUdAL LAW: A STUdy of ENGLISH HistoriCAL THOUGHT IN the Seventeenth Century: A Reissue with A Retrospect 35-41 (1987); Gerald J. Postema, Classical Common Law Jurisprudence (Part I), 2 OXford U. COMMONwwEALTH L.J. 155, 169-70 (2002). 
were to declare existing legal principles and then apply them reasonably to the situation at hand. They could do this because the principles were relatively determinate at any one point of time. Rarely did judges alter the principles themselves. Rather, they were changed insensibly, over time, simply by application. This made legal change reasonably predictable; as defenders often put it, the common law was "certain," rather than arbitrary, and because it was certain, it preserved liberty. ${ }^{14}$ The connection between the common law and English liberty was often repeated and became a motif in the eighteenth-century political rhetoric of conservative Whigs and Tories.

This perspective placed a tremendous amount of pressure on describing judicial decisionmaking in an accurate way. Did English judges actually preserve the certainty of the law by using reason to adapt it to emerging social problems? Professor Burset tells us that something of a crisis affected the common law in the mid-eighteenth century, and suggests several possible causes. ${ }^{15}$ I suspect the precise source of the crisis is important to his account. If the declaratory theory crumbled under its own intellectual weight, because its account of the law began to appear doubtful, then we make way for an intellectual explanation of the judicial abandonment of advisory opinions of the transnational form he wants to offer. On the other hand, perhaps the ultimate cause wasn't intellectual, but grew out of the social conditions in which judges were educated and worked. In that case, we might expect a local explanation to be necessary-assuming English, American, and Bengali judges did not share these conditions. Or, as I think most likely, we may need to invoke both transnational and local explanations to account for the decline of advisory opinions.

The declaratory theory of judging is usually introduced as a foil, and this is largely because modern readers have trouble understanding how one could ever find such a view persuasive as an actual account of the judicial office. The polarization, violence, and decline of civil society that America and Europe are presently experiencing make this difficulty more acute. We are evidently missing something that common lawyers of the past had, which made the declaratory theory feasible as a theoretical solution to their concerns. The "certainty" of the common law required the existence of a set of attitudes and values shared among the members of the bench and bar whose activities maintained the law. Those shared attitudes and values were born, at least in part, out of a

14. Emily Kadens, Justice Blackstone's Common Law Orthodoxy, 103 Nw. U.L. REv. 1553, 1558 (2009).

15. Burset, supra note *, at 660-61. 
process of acculturation and socialization that had long been part of English legal education at the Inns of Court. Common lawyers referred to the professional opinion produced by this process as "common erudition" or "common learning." 16 Their shared outlook was born, as well, out of a common economic and social status as gentlemen. These social forces generated a frame of mind that made "certainty" possible within the institutions where the common law was declared. As the English legal historian and theorist Brian Simpson put it, reflecting on the history of the common law, it is within "a tightly cohesive group," possessing "a wide measure of consensus upon basic ideas and values," that it becomes possible for "[a]rgument and discussion" to "commonly produce agreement in the end." 17 Without them, "[t]here is no a priori reason for supposing . . . there is a rational way of resolving disputes." 18

By the time we reach the period under study in Professor Burset's article, these constitutive social forces had weakened severely, and in some cases even lapsed. The Inns of Court began to decline in the late seventeenth century and essentially served no educational function at all by the middle of the eighteenth century. Efforts to create an institutional substitute at the English universities, such as the famous Vinerian chair at Oxford, which Blackstone occupied, were ultimately unsuccessful. ${ }^{19}$ It was recommended to young gentlemen that they spend a few years at university studying the liberal arts, and future lawyers socialized there or in pubs or university clubs. But for much of the eighteenth century, English legal education effectively lacked an institutional form. Aspiring gentlemen lawyers were left to educate themselves by reading ponderous abridgements, treatises, or other works of legal literature, and perhaps by apprenticing in the office of a lawyer, where they were likely to be busied with mechanical tasks.

What was needed now was a substitute for the shared attitudes and values that had made it possible to reach consensus about the law using lawyerly methods. What was needed was a boundary constraint, though of course no one described it in those terms: a test, an authority, a rule or maybe a procedure, for settling with certainty what the law was. We begin to see lawyers commonly citing legal writings, and especially judicial opinions, in support of their descriptions of the law.

16. J.H. BaKer, The Law's Two Bodies: Some Evidential Problems in English Legal HISTORY 67-69 (2001) (describing common learning as including "a body of received wisdom about how questions can be framed and what kinds of answers are permissible or likely to find acceptance").

17. A.W.B. Simpson, The Common Law and Legal Theory, in Legal Theory AND Legal HISTORY: ESSAYS ON THE COMMON LAW 359, 380 (1987).

18. Id.

19. David Lemmings, Professors of the LaW: Barristers and English Legal Culture IN THE EIGHTEENTH CENTURY 113-31 (2000). 
Judicial opinions long possessed an authoritative status, but they had been subsumed into the fabric of common learning by the social practice of readings at the Inns and oral deliberations conducted by the bar; now they were to stand on their own. ${ }^{20}$ As a result, legal opinions themselves changed. They began to include more lengthy written expositions of the law, purporting to show how a decision followed from, or fit alongside, an existing corpus of authority. ${ }^{21}$ The "office of judgment" held by the judge very quickly came to seem inseparable from the exposition he offered in deciding a case or announcing a principle, and writers captured this sense by defining "judicial power" as a power to "expound" the law. ${ }^{22}$

The increased importance of legal writings also carried in its wake a concern with establishing authoritative sources of the law. Which legal writings would count? ${ }^{23}$ Of course, if there were no agreement about which sources should be authoritative, sources would be unable to' play the constraining role they were needed to play-the essence of Jeremy Bentham's criticism, quoted by Professor Burset. ${ }^{24}$ Relatedly, since the words of a legal writing mattered more, the authenticity of that writing emerged as an important measure of authority. It became important to know, for instance, whether quoted language had in fact used by the judge or by learned counsel. The construction of the legal archive became a matter of more than antiquarian and constitutional concern, but an integral feature of English law and legal practice. ${ }^{25}$

Another feature of these developments is the increase, commonly observed, in the authority attributed to judicial precedent, and to the concomitant rise of a doctrine of stare decisis. Stare decisis required the judge to follow a governing decision even if convinced that it should not be followed in the present case for some other reason. ${ }^{26}$ Such a doctrine increased the certainty of the law and drew the support of the common law's most vocal critics, like Bentham. Of course, the degree of constraint provided would depend on what it meant for a previous decision to govern a present case; if "govern" were interpreted narrowly, even a doctrine of stare decisis would provide little constraint on judicial discretion. Advocates of a declaratory theory, like Blackstone, who wanted to render the law "certain" and protective of

20. See Burset, supra note *, at 663.

21. BAKER, supra note 16 , at $78,81,85$.

22. Philip Hamburger, LaW AND Judicial Duty 219-20, 226, 239 (2008).

23. SiMPSON, supra note 17 , at 380 .

24. See Burset, supra note *, at 661-62.

25. Paul Halliday, Authority in the Archives, 1 CritiCal ANALYsis of L. 110, 112-14 (2014).

26. Gerald J. Postema, Bentham and the Common LaW Tradition 187-88 (2d ed. 2019). 
liberty, sought to stitch decisions together into a system, whose principles would then deductively constrain subsequent judicial decisions. In the terminology of the period, this was to treat the law as a "science." 27 The work of fabricating a uniform legal doctrine out of a series of cases became the task of judicial exposition as well as that of legal writers producing institutes and similar legal treatises. ${ }^{28} \mathrm{As}$ Professor Burset describes, it was Mansfield more than any other English judge who was associated with the project of identifying such principles, although the differences between his views and Blackstone's could be subtle. ${ }^{29}$

The question posed regarding advisory opinions, it seems, was this: Were they the sort of legal writing that should have authoritative status as a source of law, consistent with the demand that the law be sufficiently certain to preserve English liberty? This is an intellectual question, but it grew out of social changes that had an effect on English law and legal institutions, namely, the decline of association and education of English lawyers. Throughout the period under study, the question could still be answered in different ways; several ways of thinking about advisory opinions were possible within the social and intellectual framework. The attitudes of leading English jurists toward advisory opinions, canvassed by Professor Burset in his article, nicely show this ambivalence-both the attraction and the sense of risk-and the continuing viability of advisory opinions despite the pronouncements of Sackville's Case. ${ }^{30}$ If I am right about this, then we should concede that anxiety about the common law was likely not a sufficient cause of the transnational abandonment of advisory opinions. Rather, it was at most a necessary cause: it laid the foundation for political disputes to take on constitutional content by drawing on the widespread intellectual anxiety about the certainty of the law. It seems to me that there are two geographic sources of causation operating: one transnational, which follows the English common law to its colonies, and one local, attached to colonial institutions and to the politics that affected those institutions.

27. DANiEl J. Boorstin, The Mysterious SCIEnCE OF THE LAW: AN Essay ON BLACKstone's COMMENTARIES 12, 20-21 (1941); Kadens, supra note 14, at 1559, 1580; Barbara J. Shapiro, Law and Science in Seventeenth-Century England, 21 STAN. L. REV. 727, 728-29, 755 (1969).

28. Michael LobBan, The COMmon LaW AND ENGLISH JURISPRUdENCE, 1760-1850 19, 27, 34 (1991); A.W.B. Simpson, The Rise and Fall of the Legal Treatise, in LEGAL THEORY AND LEGAL HISTORY: ESSAYS ON THE COMMON LAW 273, 280-82 (1987); BAKER, supra note 16, at 77-78.

29. Burset, supra note *, at 661.

30. See id., at 642-43, 664-66. 


\section{THE IMPERIAL SHADOW OF ENGLISH ANXIETY ABOUT THE LAW}

Let us briefly consider the case of American law. Professor Burset explores views of advisory opinions in the United States circa 1790, but this is decades after their abandonment in England and some years after the events he describes in British Bengal. What of colonial British North America in the mid-eighteenth century? Did lawyers in Britain's North American colonies experience the same intellectual anxieties about the common law? Does the available evidence suggest that their anxieties had a similar source in the socialization and training of American lawyers?

There are some important distinctions to be made here. A number of historians have described a persistent or recurrent strain of utopian anti-lawyerism in American society and politics. ${ }^{31}$ In early Massachusetts, Virginia, and elsewhere, lawyers were banned from court, and their numbers remained strikingly small in every colony (sometimes in the single digits) through the end of the seventeenth century. By the second third of the eighteenth century, however, common lawyers in several colonies had gained a foothold, both for their profession and for their body of law. The continent's first bar association opened in 1709 in New York City, which soon became a leading urban center for the practice of law. ${ }^{32} \mathrm{~A}$ handful of New York lawyers attended one of the Inns of Court, but most were trained as apprentices or "clerks" in a local law office. ${ }^{33}$ This was the dominant practice in all the colonies, excepting, to some degree, South Carolina and Virginia. In Virginia, a pretension to gentlemanly status among the planter class led to a significant number of bookish young men being dispatched to London to claim the Inn credential, but most did not practice as lawyers. ${ }^{34}$ The five Justices who signed the Correspondence renouncing advisory opinions provide a sample of the various paths open in the middle of the eighteenth century: John Jay, William Paterson, and James Wilson completed some university studies and then clerked in the office of an American attorney; John Blair, of Virginia, attended Middle Temple, one of the English Inns of Court; and James Iredell received no formal education at all, but read for the bar in a law office.

31. E.g., LAWRENCE M. FriEdman, A History of AMERICAN LAW 94-102 (2d ed. 1985).

32. 4 William E. Nelson, The Common law in Colonial america: LaW and the CONSTITUTION ON THE EVE OF INDEPENDENCE, 1735-1776, at 11 (2018).

33. Paul M. Hamlin, Legal Education in Colonial NeW York 18-21 (1939).

34. 3 William E. Nelson, The Common law in Colonial America: The Chesapeake and New ENGLAND, 1660-1750, at 47-50 (2016). 
Jay and Blair hailed from aristocratic families, but the others did not. ${ }^{35}$ By the time of their appointment to the Supreme Court, they all could claim some distinction in public life, but none was the product of a system of legal education anything like what had existed at the Inns and the courts of Westminster before the English Civil War. In America, as in England, there was simply no formal institution for socializing and training that might supply the habits of mind that had long afforced the common law.

Nevertheless, as the example suggests, throughout the North American colonies the law attracted the same stirp of ambitious gentlemen who elected the profession in England. Many of these young men sought not just wealth, but influence and honor, and they congregated with one another to that end in a variety of informal associations, such as law and debating societies, like the "Moot" of the City of New York, where, in 1770, one could find John Jay, alongside other leading men, like William Livingston, Gouverneur Morris, and James Duane. ${ }^{36}$ Apprenticeship in the law office of an important local leader could serve the same acculturating function, as appears to have been the case under the reputable George Wythe in Virginia. ${ }^{37}$ Some young men also took a course of studies in the liberal arts, hoping to refine themselves, but there seems to have been less agreement in the colonies than in England about the utility of university study for a law career. ${ }^{38}$ Candidates for the bar were usually left to read and "commonplace" (compile excerpts) from law books in private collections or an academic library, and even among the ambitious, this might mean a wide range of things. John Adams made himself into a scholar; Patrick Henry, in contrast, famously claimed to have prepared for his examination by devoting a single month to reading Coke's Institutes and a collection of Virginia's laws. ${ }^{39}$ The need to self-educate was one reason why access to libraries was so important for American lawyers.

35. William R. Casto, The Supreme Court in the Early Republic: The Chief JUSTICESHIPS OF JOHN JAY AND OLIVER ELLSWORTH 56-65 (1995).

36. HAMLIN, supra note 33, at 96-97, 201-03.

37. See Alan McKinley Smith, Virginia Lawyers, 1680-1776: The Birth of a Profession, 43 (1967) (Ph.D. dissertation, Johns Hopkins University).

38. For example, a letter from Henry Tucker to his son, the future Virginia jurist, St. George Tucker, asks why he has enrolled in classes in philosophy and mathematics, which were part of "an Academical Education" but of no use in practicing law. Id. at 39-40 (quoting Letter from Henry Tucker to St. George Tucker (Apr. 10, 1772)). Henry was concerned about the cost of his son's university education. On the other hand, the Inns of Court were also expensive, and they provided no education at all. HAMLIN, supra note 33 , at 21-22, 115-16.

39. On education by reading and commonplacing, see, e.g., JEFFERSON'S LEGAL CommonPlace BooK, 1-3, 6 (David Thomas Konig \& Michael P. Zuckert eds., 2019); Steilen, supra note 11, at 520-26 (describing the legal education of Thomas Jefferson and Patrick Henry). Cf. H. Trevor Colbourn, The LAMP of ExPeRIEnCE: Whig History and the InTELleCtual Origins 
Perhaps more than in England, the American evidence suggests the existence of an important social distance between the young, college-educated, aspiring lawyer-statesmen and the lawmakers who sat in provincial assemblies and on juries and even the judicial bench. ${ }^{40}$ In Virginia these social divisions matured over the last quarter of the eighteenth century into partisan political controversies about the structure of the state's legal system and the practice of law. The rhetoric of these controversies shared much in common with coeval English rhetoric about lawyers and liberty; thus, for example, an eminent Virginia planter and slave-owner, Landon Carter, dismissed what he called the "mechanical" knowledge of professional lawyers, whose training had prepared them only for "knowing from whom to Copy Properly"-a reference to the forms and manuals that were popular in legal practice. ${ }^{41}$ (The justices of the peace, for their part, were often criticized for failing to observe established legal forms in their papers and proceedings.) But the opposite of "mechanical" knowledgelawyerly discretion - also caused anxiety, and in Virginia it triggered a defensive embrace of the local office of justice of the peace, usually filled by planters, rather than a centralized court system dominated by the educated legal elite practicing in Williamsburg. Supporters of the justices defended their wide jurisdiction and the insulation of their judgments from effective appellate review by invoking the language of radical English "country" politics, arguing that they protected liberty and staved off the corruption of centralized power. ${ }^{42}$

These political disputes can be connected with theoretical claims about the law much like those we observed in England. In responding to their country critics, lawyers made use of the same ideas to emphasize the narrowness of judicial discretion and the certainty of the law. They embraced the familiar declaratory theory: that the task of the judge was merely to identify and declare legal principles, not to make or alter those principles. ${ }^{43}$ They sought to craft their opinions in a "deductivist" style-that is, to convey an impression that legal

OF THE AMERICAN REVOLUTION 9-20 (1965) (describing the importance of libraries for ideas and politics in colonial America).

40. LEMmings, supra note 19, at 242-44; Hulsebosch, supra note 3, at 127-28. Studies of this division in individual colonies include the aforementioned Hulsebosch; JOHN PHILLIP REID, Controlling the LaW: Legal Politics in EARly National New HAMPshiRe 4-9 (2004); Smith, supra note 37 , at 8-10.

41. The Diary of Colonel Landon Carter of Sabine Hall, 1752-1778, at 93 (Jack P. Greene ed., 1987). In England, we also find criticisms of legal education as being "mechanical" and lawyers "illiterate." LEMMINGS, supra note 19, at 115, 145.

42. The classic study is A.G. Roeber, Faithful Magistrates and REPUblican Lawyers: Creators of Virginia LEGAl Culture, 1680-1810, at 32-72, 112-59 (1981).

43. G. Edward White With Gerald Gunther, The Marshall Court and Cultural CHANGE, 1815-1835, at 195-96 (1988). 
principles deductively compelled a particular answer, and thus constrained judicial discretion. Perhaps the most successful practitioner of this method (ever) was a young Virginia lawyer named John Marshall. ${ }^{44}$ The attraction of deductivism to American lawyers may explain why, as historians have observed, Blackstone's Commentaries was more popular in the United States than in England, where it invited significant criticism. ${ }^{45}$ In America, an edition of Blackstone edited by the Virginia jurist, St. George Tucker, was an immediate success and held its place as the preeminent learned American lawbook for nearly twenty years. ${ }^{46}$

Tucker contributed, as well, to solving another of the problems faced by American jurists in this period, which was the dearth of properly "republican" legal authorities. The principles in Blackstone's Commentaries were not consistent with republican government because they had not been adopted with consent. ${ }^{47}$ Tucker, Marshall, and other lawyers began to create case reports, raw materials for a republican common law, and by the early nineteenth century we can observe the emergence of a judicial practice of accumulating precedents in a lengthy written opinion, much like Blackstone had done on the English bench. Judge Tucker developed this art to such a degree that an alienated colleague on Virginia's General Court, Spencer Roane, finally ripped one of Tucker's opinions from his hands as he was reading it at conference and threw it on the floor, declaring that he refused to hear another of his "long, tedious, and ridiculous" opinions." 48 Other treatises written in the institute style joined Tucker's Blackstone, including the Commentaries on American Law of the great New York judge, James Kent. ${ }^{49}$ This style of legal literature supported a view of the law as a system of principles, from which results in a case would determinately flow.

44. Charles F. Hobson, The Great Chief Justice: John Marshall and the Rule of LaW 32-35 (1996).

45. On English criticisms of Blackstone, see LOBBAN, supra note 28, at 47-50, 56-61 (arguing that Blackstone was "lazy and inept as a researcher, and that he did not go deeply enough into the history of the ancient laws to explain the modern law").

46. 1 William Blackstone \& St. George Tucker, Blackstone's Commentaries: With NOTES OF REFERENCE, TO THE CONSTITUTION AND LAWS, OF THE FEDERAL GOVERNMENT OF THE United States; AND of the Commonwealth of Virginia xiii (Paul Finkelman \& David Cobin eds., 1996) (1803).

47. Kunal M. PARKer, COMmon LaW, History, AND DEMOCRACY In AMERICA, 1790-1900, at 104-05 (2011).

48. Matthew Steilen, A Virginia Perspective on McCulloch 23-26 (Nov. 2018) (unpublished manuscript) (on file with author); 1 ST. GEORGE TUCKER'S LAW REPORTS AND SELECTED PAPERS, 1782-1825, at 89-90, 101 (Charles F. Hobson ed., 2013). On Judge Blackstone's habit of "lining up . . . authorities," see Kadens, supra note 14, at 1585.

49. John H. Langbein, Chancellor Kent and the History of Legal Literature, 93 ColuM. L. REV. (1993). 
A full picture of these developments would require much more than the quick sketch I have given here. But we have enough, I think, to suggest the operative question for Professor Burset's account of the British colony of Bengal: were its judges operating under social and political pressures like those in England and America? If so, did they induce writers to emphasize restrictions on judicial discretion? Was there a need, grounded in the same concerns, to identify authoritative sources of law? Or, on the other hand, were the actions and writings of officials in British Bengal guided by a different set of concerns, unique to that colony?

\section{THE INSTITUTIONAL DIMENSION OF INTELLECTUAL ANXIETY AND ITS CONNECTION TO LOCAL POLITICS}

By the time of the Correspondence of the Justices, in 1793, advisory opinions had been in question in America for some time. ${ }^{50}$ If the absence of an institutional seat for lawyerly acculturation, association, and training led to an anxiety about judicial discretion and the authoritative status of advisory opinions, as I have suggested, then these causes seem to have been at work both in metropolitan England and its North American colonial periphery. Although it is complex, I do think we can call this a transnational explanation. But if we want to understand the relatively late timing of the formal abandonment of advisory opinions in America, it seems right to consider another factor as well: institutions.

Let us start in an "old-fashioned" way, with a formal description. There was general agreement at the Constitutional Convention on the need for a national judicial power; on its vesting in a single, supreme, national court; on the court's possession of a jurisdiction sufficient to vindicate national interests; and the need for the judges of that court to be independent by tenure and salary. ${ }^{51}$ The system of federal judges, federal courts, and federal jurisdiction constituted by Article III and the Judiciary Act of 1789 largely reflects this scope of agreement.52 Although there was as of yet no general grant of what we know as "federal question jurisdiction," the Act established a jurisdiction over civil enforcement actions and a system of federal district courts in which those actions might be brought, by federal attorneys, before federal judges. There was an appellate jurisdiction in the Supreme Court to

50. See Burset, supra note *, at 651 .

51. This is a conventional view of the framing of the federal judicial power. See, e.g., RICHARD H. FAllon, JR. ET AL., HART AND Wechsler's The Federal Courts AND THE FEDERAL System ch. 1 (7th ed. 2015).

52. U.S. CoNST. art. III, §§ 1-2; Judiciary Act of 1789, ch. 20, 1 Stat. 73. 
protect the Constitution and federal treaties from encroachment in state courts. An apparatus for the vigorous enforcement of federal law had been erected. In contrast, the Supreme Court of Judicature (SCJ) at Fort William, Bengal, had a different formal structure. Its judges were not independent in the same way; they held their seats at the pleasure of the Crown and, it seems, might be removed by legislative address-a power expressly rejected by the delegates at the Constitutional Convention. ${ }^{53}$ The SCJ's jurisdiction was narrower than the jurisdiction of the federal courts, being largely confined to employees of the British East India Company and to those Bengalis who accepted it. What relevance do these formal, institutional differences have for interpreting the statements of judges who sat on the respective courts? They provide a framework for interpreting their statements, since it seems likely the formal structure of their courts influenced judges' perception of institutional purposes and risks.

We should also consider the resources available to these institutions, including people-that is, staff or personnel-since this can have a profound effect on the scope and development of institutional authority and the legal doctrines that describe it. Thus, it is sometimes observed that during the Confederation and Federalist periods of American history, there were few men qualified to give legal advice on delicate questions of state. As a result, perhaps, many elite lawyers and judges were recruited to serve in foreign-affairs roles. ${ }^{54}$ Once in this station, the men acquired further institutional expertise, increasing the state's dependence on them. In this way, the small number of elite Americans trusted to conduct foreign affairs reinforced the traditional English practice of advisory opinions that Professor Burset describes. ${ }^{55}$

It is also often observed that there was a general blurring of institutional boundaries between the great departments of the national government. This was related to personnel, but it was not just a matter of failing to separate persons; it also reflected the existence of conceptions, quite different from our own, of the proper powers of the departments of government. ${ }^{56}$ Most relevant here, early Americans

53. 2 The Records of the Federal Convention of 1787, at 428-29 (Max Farrand ed., 1911). My understanding of the tenure of judges who sat on the SCJ is based on correspondence with Professor Burset. On recall by address, see ELIJAH BARWELL IMPEY, MEMOIRS OF SIR ELIJAH IMPEY 270 (1857).

54. Stewart Jay, Most Humble Servants: The Advisory Role of Early Judges 95 (1997).

55. See Burset, supra note *, at 631-37 (describing advice-giving under the classical common law).

56. Id. at 52; see generally William B. Gwyn, The Indeterminacy of the Separation of Powers in the Age of the Framers, 30 WM. \& MARY L. REV. 263 (1989) (describing the lack of clarity and agreement surrounding the separation of powers doctrine). 
seem to have conceived of their "independent" judicial power without the great emphasis we place today on the doctrine of justiciability. Here we should mention the practice by early Supreme Court justices of giving partisan jury charges, which passed beyond the case at hand and well into the realm of political speech; as well as the justices' efforts to reinforce a tottering federal government by playing what the historian Ralph Lerner called "Republican Schoolmaster" to the multitudes gathered for a session of court. ${ }^{57}$ Though they persisted for some time, these activities were losing ground in the last decades of the eighteenth century. In our other jurisdictions, England and Bengal, we can also see inklings of a doctrine of ripeness, finality, and something like a principle of constitutional avoidance-notions that appear to have been imperfectly distinguished from the discomfort with advisory opinions. ${ }^{58}$ Reviewing the evidence gives one the sense of witnessing the birth of a doctrine, whose precise contours were yet those of contemporary justiciability, but which was bound up quite closely with the institutional development of the judiciary. As the doctrine matured, the institutional range of judicial power simultaneously narrowed and firmed.

The emerging desire to constrain the judicial office to the adjudication of litigated cases could have surprising effects, some of which may complicate Professor Burset's account. Thus, according to a conventional understanding of the development of judicial review, conservative legal elites pushed for a judicial power to refuse to give effect to legislation as a means of curbing state assemblies under the influence of popular faction. ${ }^{59}$ Delegates at the Constitutional Convention were quite anxious to preserve this power against accusations of bias, such as might be invited if judges participated in the veto power by sitting on a "Council of Revision." 60 Judges injected into the political process of making law would be unable to exercise impartially their office of "expounding" the law when it came before

57. Ralph Lerner, The Supreme Court as Republican Schoolmaster, 1967 S. CT. REV. 127 (1967); see also Russell Wheeler, Extrajudicial Activities of the Early Supreme Court, 1973 S. CT. REV. 123, 125-31 (1973) (describing disagreements over the bounds of judges' powers).

58. For ripeness, see Kadens, supra note 14, at 1582-85 (describing several cases in which judges refused to join decisions for fear of judicial overreach). Doctrines of finality and constitutional avoidance are suggested by Professor Burset's discussion of Bengal. Burset, supra note*, at 26,28 . Constitutional avoidance is not usually thought of as a justiciability doctrine, but it can be compared to the Bickelian interpretation of political question doctrine, that is, as a prudential refusal to answer a question of law presented in a case.

59. See, e.g., Larry D. Kramer, The People Themselves: Popular Constitutionalism AND JUDICIAL REVIEW 54-64 (2004) (describing the origins of judicial review and its justifications).

60. E.g., 1 THE RECORDS OF THE FEDERAL CONVENTION OF 1787, at 108-09 (Max Farrand ed., 1911) (statement of Mr. King); THE RECORDS OF THE FEDERAL CONVENTION OF 1787, supra note 53, at 79 (statement of Mr. Ghorum). 
them in a case, which implied a power of judicial review. ${ }^{61}$ The irony, however, is that the power of judicial review ended up repeatedly injecting federal judges into matters of acute political controversy. If judges declined to give advisory opinions because they feared their partisan misuse, as Professor Burset argues, why would the same judges continue to strike down laws in the face of vitriolic partisan responses, such as were engendered in cases like McCulloch $v$. Maryland ${ }^{62}$ Justice Marshall had to work over a number of years to fully establish an institutional power in the Court to review congressional statutes and presidential acts. ${ }^{63} \mathrm{He}$ had no greater control over the use and reception of his judicial opinions than he did over extrajudicial statements; and the Court's authority to issue judgments expanding national power and narrowing or invalidating state power was repeatedly challenged. Perhaps we should say that an institution itself can acquire developmental momentum, a selfunderstanding and ethos, and that this momentum can carry its occupants on a trajectory they might otherwise not have elected, for fear of the political risk.

It seems clear that the relationship of an intellectual anxiety about the authority of law, institutional form, politics, and legal doctrine could be extremely complex, and might involve overlapping, reinforcing, or conflicting imperial and local strands. If we turn to Professor Burset's reconstruction of events in British-governed Bengal in the decades after the Regulating Act, I find it tempting to see multiple connections between local politics, institutional form, and an emerging doctrine of justiciability. The SCJ authorized by the Regulating Act and chartered by the Crown was intended to curb the power of the British East India Company (Company), which had grown so mighty that it mimicked an imperial power. ${ }^{64}$ To serve that end, British legislators thought it vital that the Court maintain its independence from company power. When Justice Impey, whose correspondence forms the basis of Professor Burset's account, accepted a second judgeship with a company court, members of the House of Commons were angered, and resolved that he be made to "answer the charge of having accepted an office granted by, and tenable at, the

61. Matthew Steilen, Judicial Review and Non-Enforcement at the Founding, 17 U. PA. J. Const. L. 479, 555-58, 561-63 (2014); EDWARD S. CoRwIN, The PREsIdENT: OfFICE AND Powers, 1787-1984, at 561 (Randall W. Bland et al. eds., 5th ed. 1984).

62. John MARShall’s Defense of McCulloch v. Maryland 1-21 (Gerald Gunther ed., 1969).

63. Mark Graber, Establishing Judicial Review? Schooner Peggy and the Early Marshall Court, 51 PoL. RSCH. Q. 221, 224 (1998).

64. BENTON, supra note 3, at 135-36. 
pleasure of the servants of the East India Company, which has a tendency to create a dependence in the said Supreme Court upon those over whose actions the said Court was intended as a controul." 65 The justices seem to have grasped this danger themselves, and asserted their powers, or held them in check, according to the effect on their court's constitutional function.

Thus, for example, from the beginning of questions triggered by Nandakumar's confinement, Justice Impey expresses a concern that the court not take steps that undermine what Professor Burset calls "the appearance of impartiality." 66 Apparently it was important that the court's control over the Company be exercised judicially, rather than politically. This required the observable maintenance of a formal separation between the court and council. In a subsequent letter, Impey asserted on behalf of the entire court that the council lacked "any legal authority ... to review and control any judicial acts of the judges done either in or out of court." 67 The letter itself is an advisory opinion (of a sort) and expressly defends the judges' right to act independent of council control "out of court." The justiciability doctrine advanced here is therefore not the inappropriateness of advisory opinions, but the finality of judicial acts (in or out of court), as is conventionally represented in American jurisprudence by Hayburn's Case. ${ }^{68}$ The final letter in the affair returns to this theme of independence by finality and the appearance of impartiality. The SCJ, wrote the judges, is "not in general justifiable" by the council. Its decisions are final. Since, however, the question now posed by the council could not come before the court judicially, its independence was not at risk and it could provide an opinion. ${ }^{69}$

A resistance to giving advisory opinions clearly formed part of these events, but a willingness to give those opinions ultimately resolved the controversy over jurisdiction, and the firm ground to which the court retreated was its independence. The subsequent crisis over whether Warren Hastings or John Clavering was Governor-General exhibits a similar logic. When asked to decide who was lawfully governor, the court agreed to give its opinion only so long as it was treated as mere advice, rather than a judgment (an opinion whose

65. 2 James FitzJames Stephen, The Story of Nuncomar AND the ImPeAchment of SiR ELIJAH IMPEY 6 (1885) (emphasis added). Professor Burset kindly directed me to this quotation.

66. Burset, supra note *, at 645 .

67. Id., at 647 .

68. FALLON, JR. ET AL., supra note 51, at 81-94.

69. Burset, supra note *, at 647. 
weight derived "from the reasoning of it, not from its authority"). ${ }^{70}$ The court's apparent worry was losing its independence, since a judgment in favor of the Governor-General would imply some connection between them.

It does seem right to conclude, as Professor Burset does, that an uncertainty about the authority of advisory opinions exposed judges to risk. ${ }^{71} \mathrm{~A}$ politician might solicit judicial advice and use it to shift blame for an unpopular decision to the judge. A judge might be accused of bias in a subsequent case that raised a legal question on which he already offered his opinion out of court. Should we explain the abandonment of advisory opinions as an effort by judges to avoid these risks, in light of an intellectual anxiety shared across the common-law world? Or should we conclude that these risks became part of a complex practical calculus, in which judges balanced worries about the misuse of advisory opinions with institutional and political concerns that sometimes pointed in a different direction? Sometimes judges simultaneously gave advice and declared that they were not under an obligation to do so; and sometimes they deliberately spoke out of court to defend what they perceived to be institutional rights or prerogatives; and sometimes they injected themselves into the midst of political controversy by using their decisions in litigated cases, despite the personal and institutional risks that doing so posed. These are some of the complexities that we must consider as we move forward with the project of understanding our federal judicial power from an imperial perspective. 